Study Abroad

AN international handbook published by U.N.E.S.C.O. gives full information on all available opportunities for trans-national study, including scholarships, fellowships, and international training programmes.

Lists of fellowships and scholarships are given, with details of subjects, locality, conditions of tenure, \&c., together with an index of fields of study and beneficiary countries. An introductory chapter describes the development of international fellowship and travel study programmes, with notes on the programmes initiated by various member states of U.N.E.S.C.O. and by other agencies.

\title{
Lugard Memorial Lecture
}

The Executive Council of the Institute, at its meeting in Paris, resolved to invite Miss Margery Perham, Fellow of Nuffield College, Oxford, and member of the Executive Council, to give the Lugard Memorial Lecture in I950.

Miss Perham has accepted the invitation, and has suggested as the subject of her lecture some aspects of the life and work of Lord Lugard. The lecture will probably be given at the meeting of the Institute's Executive Council in 1950.

\section{Current and prospective field researches in Nigeria}

Mr. and Mrs. D. P. L. Dry, of Oxford University, awarded a Horniman Field Studentship by the Royal Anthropological Institute of Great Britain, are engaged in an intensive study of the social organization of a series of Hausa communities in the Zaria Province, including Soba.

Mr. M. G. Smith, of University College, London, has been awarded a Colonial Office Studentship for socio-economic studies in Zaria Province, and will make a comparative study of social and economic organization and levels of economic development in both Hausa and 'pagan' areas. Mr. Smith is proceeding to the field in May for a period of eighteen months.

Mr. W. B. Schwab, of the University of Pennsylvania, is undertaking a preparatory period of study at University College, London, before proceeding to Nigeria to undertake a study of social and economic conditions in an urban community among the Yoruba.

Mr. D. P. M. Morton-Williams, of University College, London, has been awarded a Horniman Studentship for a field study of Yoruba social organization and will proceed to Nigeria in 1950 after a period of preparatory training.

\section{A Nutritional Survey of the Republic of Liberia}

Dr. Flemmie P. Kittrell of Howard University, Washington, D.C., visited the Republic of Liberia between December 1946 and June 1947 to undertake a survey of native diet and nutrition. Her report, entitled A Preliminary Food and Nutrition Survey of Liberia, West Africa, has recently become available. The data on which the report is based include an examination of the dry-season diet of about 4,500 individuals from various parts of the Republic, supplemented by clinical information from the laboratory of the Firestone Plantations Company, its hospitals at Harbel and Cape Palmas, from the Samuel Grimes Maternal and Child Welfare Centre at Kakata, and the Ganta Health Mission at Ganta. The I945 revision of the National Research Council's Nutrition Yardstick was used to assess the adequacy of diets.

Although Liberians use a wide variety of foods, at certain seasons the number of foods

I Study Abroad, International Handbook, vol. i. U.N.E.S.C.O., Paris, 1948. U.N.E.S.C.O. publication 234. 